\title{
A Survey of Virginia Vineyards Revealed High Incidences of Grapevine Rupestris Stem Pitting-Associated Virus, Grapevine Red Blotch Virus, and Two Mealybug Species
}

\author{
Taylor Jones and Mizuho $\mathrm{Nita}^{\dagger}$ \\ Alson H. Smith Jr. Agricultural Research and Extension Center, Virginia Polytechnic Institute and State University, Winchester, VA
}

Accepted for publication 24 July 2019.

\begin{abstract}
We investigated the prevalence of viruses infecting grapevines in Virginia, identity of disease vectors, and potential factors affecting virus incidence. Tested viruses were grapevine leafrollassociated virus (GLRaV-1 and -4), grapevine fleck virus (GFkV), grapevine virus $A(G V A)$, grapevine virus $B(G V B)$, grapevine rupestris stem pitting-associated virus (GRSPaV), tomato ringspot virus (ToRSV), grapevine vein clearing virus (GVCV), grapevine red blotch virus (GRBV), and grapevine Pinot gris virus (GPGV). We documented wide distributions of GRSPaV (54\%) and GRBV (24\%) and common occurrences of grape (Pseudococcus maritimus) and Gill's (Ferrisia gilli) mealybugs among vineyards. This is the first report of GLRaV-1, GLRaV-4, GVA, GVB, GRSPaV, and obscure mealybug (Pseudococcus viburni) in Virginia. We also documented significant
\end{abstract}

Abstract association $(P \leq 0.05)$ of the presence of mealybugs and GVA and GVB. With younger vines, significantly lower incidences were found for viruses that were listed (i.e., tested for a certification) by the Foundation Planting Service's and the National Clean Plant Network's grape programs. On the other hand, there was a lack of the age effect on incidence of GRSPaV and GRBV, which were not listed until recently. These results suggest the importance of clean plant material and vector management for grapevine virus disease management in Virginia.

Keywords: grapevine leafroll-associated virus, grapevine virus $A$, grapevine virus $B$, grapevine rupestris stem-pitting virus, tomato ringspot virus, grapevine red blotch virus, Pseudococcus viburni
There are more than 70 viruses and virus-like organisms associated with grapevines (Vitis spp.) (Martelli 2014). Many of these grapevine viruses do not pose a threat to wine grape production, but some can cause serious negative economic impact. For example, grapevine leafroll disease causes crop loss ranging from 10 to $40 \%$ by reducing sugar and anthocyanin accumulation in berries (Kovacs et al. 2001; Naidu et al. 2014; Wolpert and Vilas 1992). The causal agents of grapevine leafroll disease are grapevine leafroll-associated viruses (GLRaVs, family Closteroviridae), which includes GLRaV-2 (genus Closterovirus), GLRaV-7 (genus Velarivirus), and GLRaV-1, -3, and -4 (genus Ampelovirus; GLRaV-4 has strains 5, 6, 9, De, Pr, and Car) (Abou Ghanem-Sabanadzovic et al. 2012; Jelkmann et al. 2012; Martelli et al. 2012). In our previous study (Jones et al. 2015), we found a high number of GLRaV-3 infected vines among Virginia vineyards.

Grapevine red blotch virus (GRBV, family Geminiviridae, also known as grapevine Cabernet franc-associated virus and grapevine redleaf disease) has been found in multiple wine grape-growing states in the United States (Al Rwahnih et al. 2013; Krenz et al. 2012) such as California, Maryland, New York, New Jersey, Oregon, Pennsylvania, Virginia, and Washington (Krenz et al.

${ }^{\dagger}$ Corresponding author: M. Nita; E-mail: nita24@vt.edu

Funding: This work was funded by the Virginia Wine Board (2011 to 2015, grant no. 12-2001-03).

The author(s) declare no conflict of interest.

(C) 2019 The American Phytopathological Society
2014). Symptoms are similar to those of GLRaVs, with notable reductions in quality and quantity of the yield (Al Rwahnih et al. 2013; Blanco-Ulate et al. 2017). A recent report suggests the threecornered alfalfa treehopper (Spissistilus festinus, a minor alfalfa pest in Virginia) as a vector of GRBV (Bahder et al. 2016).

The rugose wood disease complex is caused by a group of viruses, most belonging to the genera Vitivirus and Foveavirus of the family Betaflexiviridae. This complex includes grapevine virus A (GVA), grapevine virus B (GVB), and grapevine rupestris stempitting associated virus (GRSPaV). These viruses primarily affect the vascular system of infected grapevines to cause slow decline, stem grooving (GVA), corky bark (GVB), and graft incompatibility (Boscia et al. 1993; Rosa et al. 2011). Irregular to no ripening of berries can occur with infections of these viruses, and symptoms may become more severe when multiple viruses infect the same vine (such as GLRaV-3) (Guidoni et al. 1997).

Tomato ringspot virus (ToRSV) is transmitted by the dagger nematode (Xiphinema americanum) (Rosenberger et al. 1983; Teliz et al. 1966). ToRSV infection causes uneven fruit development, a significant loss in yield, and overall vine decline (Uyemoto et al. 1977). In a study conducted in 1984, ToRSV was commonly present among Virginia vineyards (Tuskan and Tolin 1984); however, information from recent plantings is not known. The risk this virus poses in Virginia vineyards is potentially high with susceptible own-rooted hybrid cultivars, such as Vidal blanc (60.7 bearing hectares producing 623 metric tons in 2015) and Seyval (12.95 bearing hectares producing 105 metric tons in 2015).

Grapevine vein clearing virus (GVCV, family Caulimoviridae, genus Badnavirus) has been found primarily in the midwestern 
states in the United States and causes severe translucent vein clearing, vine decline, and yield reduction with Vitis vinifera (Guo et al. 2014; Zhang et al. 2011). Although a study showed a spread of infected vines within a field, its vector has not been identified. Mixed infection of GVCV with grapevine fanleaf virus, ToRSV, and/or GRSPaV is associated with severe symptom expression (Lunden et al. 2010; Qiu 2007).

Recent studies in Europe showed incidences of grapevine Pinot gris virus (GPGV, genus Trichovirus, family Betaflexiviridae) in Italy, France, the Czech Republic, and Slovenia (Giampetruzzi et al. 2012; Morelli et al. 2014; Saldarelli et al. 2015). GPGV negatively affects shoot production as well as berry number and weight per vine.

Virginia has an expanding wine industry with more than 1,400 bearing hectares with $\$ 1.4$ billion annual economic impact (Virginia Wine Board 2017). However, our previous survey showed the presence of GLRaV-2 and -3 throughout the state (Jones et al. 2015). In particular, GLRaV-3 was found in $64 \%$ of surveyed vineyards. Virginia growers generally agree that the degree of damage varies by year and location, but several growers suffered severe crop loss owing to GLRaV-3, which resulted in complete replants of the affected blocks (Nita, personal communication). However, current understanding of other grapevine viruses in Virginia is limited. In addition, the grape ( $P$. maritimus) and Gill's ( $F$. gilli) mealybugs, which are vectors of multiple grapevine viruses including GLRaVs and GVA (Bahder et al. 2013; Cooper et al. 2018; Golino et al. 2002; Rosciglione and Castellano 1985; Wistrom et al. 2016), were found among Virginia vineyards (Jones et al. 2015).

The objectives of this study were to examine the current state of grapevine virus infection in the state of Virginia with the exception GLRaV-2 and -3 , to investigate potential factors that may influence virus incidence, and to determine species of mealybugs currently present in Virginia.

\section{Sample Collection and Identification Procedures for Grapevine Viruses}

Samples were collected throughout the 2009 to 2014 seasons. A total of 116 vineyards were selected randomly across the major grape-growing regions of Virginia (Fig. 1). At each vineyard, multiple cultivars were randomly selected and sampled. Within a cultivar block, one to two vines were arbitrarily selected. Some vines expressed a certain level of stress symptoms (e.g., discoloration of leaves, lack of vigor, stunted shoot growth, etc.; Fig. 2), whereas others were nonsymptomatic. From each vine, a sample consisting of 10 petioles was taken arbitrarily within the canopy. The reason for arbitrary sampling was to account for uneven virus distribution in grapevines (Charles et al. 2006). Sampled petioles were placed into a 0.94-liter plastic bag, immediately stored in an iced cooler, and taken back to the laboratory. Samples were then immediately processed into a total extract (Jones et al. 2015) or stored at $-20^{\circ} \mathrm{C}$ and processed within a few days. Sample information such as cultivar, presence/absence of mealybugs, and age of planting was also recorded along with the location data.

Grape extracts were prepared as described in Jones et al. (2015) and processed for a one-step reverse-transcription PCR (RT-PCR)

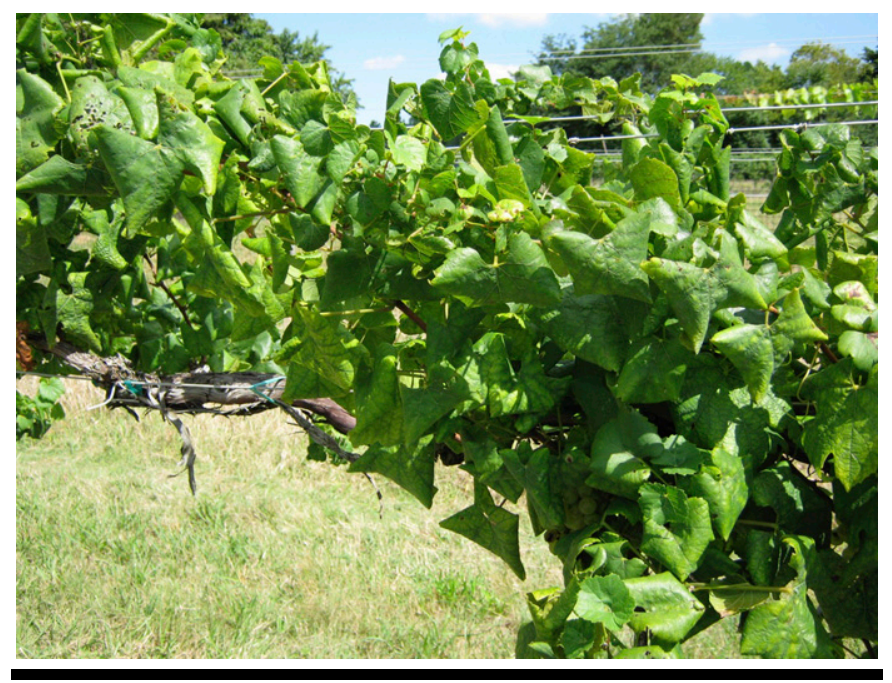

FIGURE 2

An example of a symptomatic vine (cv. Chardonnay) showing cupping and discoloration of leaves and reduced vigor owing to the virus infection. This vine was positive for GLRaV-3, GVA, and GVB.

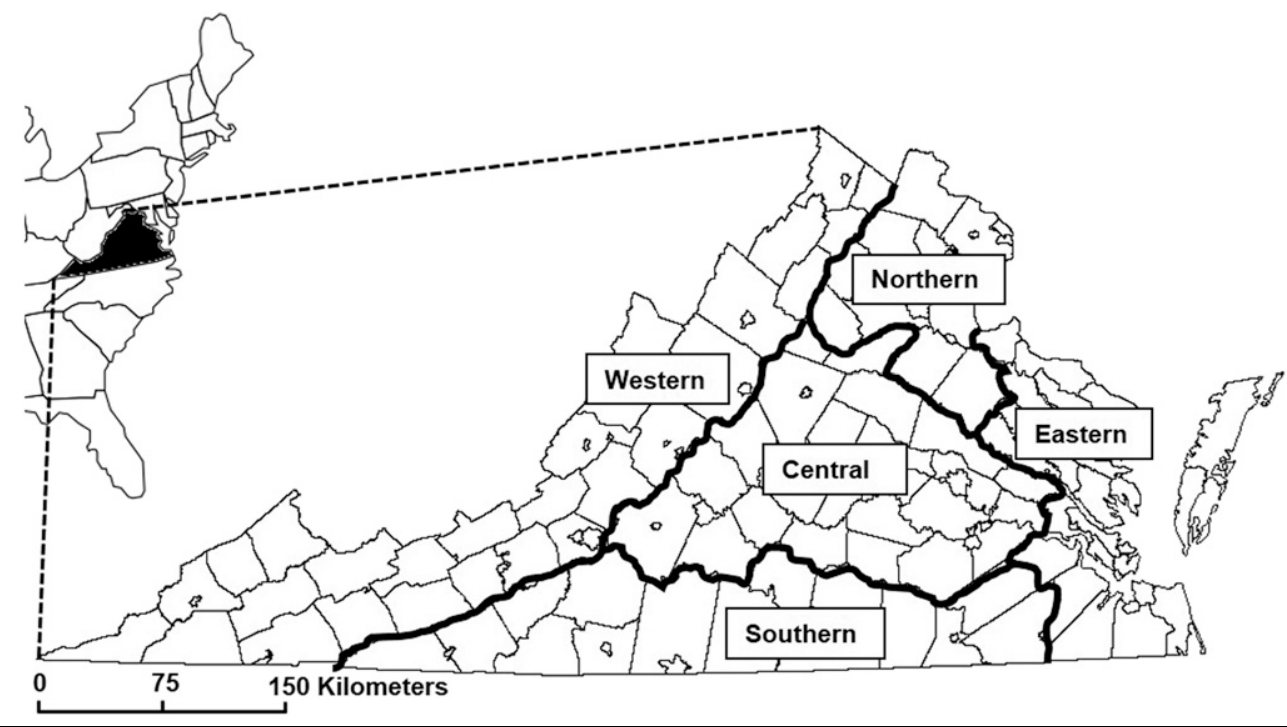

FIGURE 1

The state of Virginia (U.S.A.) and its five regions used in the Virginia grapevine virus survey in 2009 to 2014. The majority of vineyards and wineries are located in the Northern and Central regions. 
for all RNA viruses (Rowhani et al. 2000), and we followed a PCR protocol from Al Rwahnih et al. (2013) for GRBV (Table 1). For virus detection using PCR and RT-PCR, $4 \mu \mathrm{l}$ of extract was added to $50 \mu \mathrm{l}$ of GES denaturing buffer $(0.1 \mathrm{M}$ glycine, $\mathrm{pH} 9.0 ; 50 \mathrm{mM}$ $\mathrm{NaCl} ; 1 \mathrm{mM}$ EDTA; $0.5 \%$ Triton $\mathrm{X}-100$ ) in a $0.5-\mathrm{ml}$ microcentrifuge tube. Following incubation at $95^{\circ} \mathrm{C}$ for $10 \mathrm{~min}$, samples were placed on ice for a minimum of 5 min before adding $2 \mu \mathrm{l}$ of the GES-denatured homogenate, $13.4 \mu \mathrm{l}$ of nuclease-free $\mathrm{H}_{2} \mathrm{O}, 2.5 \mu \mathrm{l}$ of 10x PCR buffer (New England Biolabs, Ipswich, MA), $2.5 \mu \mathrm{l}$ of sucrose/cresol red (20\% w/v sucrose, $1 \mathrm{mM}$ cresol red, SigmaAldrich, St. Louis, MO), $1.25 \mu \mathrm{l}$ of virus-specific forward primer $(20 \mu \mathrm{M}), 1.25 \mu \mathrm{l}$ of virus-specific reverse primer $(20 \mu \mathrm{M}), 1.25 \mu \mathrm{l}$ of $100 \mathrm{mM}$ dithiothreitol (Sigma-Aldrich), $0.5 \mu \mathrm{l}$ of dNTPs $(10 \mathrm{mM}$, Invitrogen, Grand Island, NY), $0.1 \mu \mathrm{l}$ of RNaseOUT (40 U/ $\mu \mathrm{l}$ ) (Invitrogen), $0.035 \mu \mathrm{l}$ of Superscript III RTase (200 U/ $\mu \mathrm{l})$ (Invitrogen), and $0.25 \mu \mathrm{l}$ of Taq DNA polymerase ( $5 \mathrm{U} / \mu \mathrm{l})$ (New England Biolabs). For PCR reactions, $0.135 \mu \mathrm{l}$ of PCR-grade water was included as a substitute for the RTase and RNaseOUT.

Following amplification in a thermal cycler (Bio-Rad C1000, Hercules, CA) (Table 1), gel electrophoresis with a 1.2\% agarose gel was used to visualize DNA fragments, and gel pictures were taken with a digital imaging system (Fotodyne, Hartland, WI). Positive (a sample from a previously known infected vine) and negative (water) controls were used for each gel to validate test results.

Several amplified DNA samples were randomly selected from PCR-positive samples for each virus. These samples were purified using the QIAquick PCR Purification kit (Qiagen, Valencia, CA) using the manufacturer's protocol and then sequenced to confirm identity of viruses and validity of amplification techniques. Sanger sequencing was completed with an ABI 3730 DNA sequencer (Applied Biosystems, Foster City, CA) at the Biocomplexity Institute of Virginia Tech (Blacksburg, VA). Multiple sequence alignments were performed with Clustal X (Conway Institute, Dublin, Ireland) for the HSP70h of GLRaV-1 and -4 (including GLRaV-5 and -9), the replicase gene of GRSPaV, the coat protein of GVA and GVB, and the V2 gene of GRBV under default parameters.

\section{GRSPaV and GRBV are Widespread in Virginia}

Samples were collected from a total of 116 Virginia vineyards during 2011 to 2014 . Numbers of vineyards sampled among five different regions were as follows: Northern (40), Southern (8), Eastern (22), Western (12), and Central (34) (Fig. 1). A total of 574

\begin{tabular}{|c|c|c|c|c|c|c|}
\hline \multicolumn{7}{|c|}{ 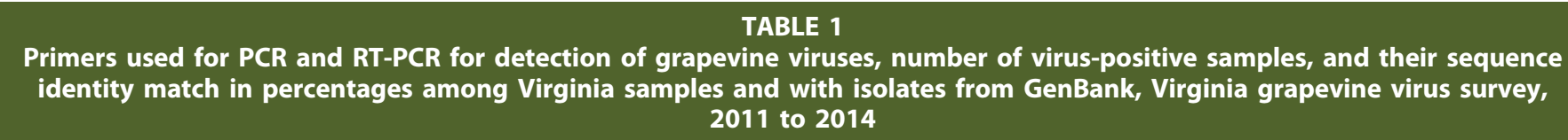 } \\
\hline GLRaV-1 & $\begin{array}{l}\text { LR1-hsp401 F/LR1-hsp401 R } \\
\text { (Osman et al. 2007) }\end{array}$ & 54 & MK317841 & $9(1.3)$ & $4(96-99)$ & 26 \\
\hline \multirow{2}{*}{ GLRaV-4x } & $\begin{array}{l}\text { LR9 F/LR9 R (strain 9) (Alkowni } \\
\text { et al. 2004) }\end{array}$ & 54 & MN175643 & $3(0.4)$ & $\mathrm{n} / \mathrm{a}$ & 11 \\
\hline & $\begin{array}{l}\text { LRAmp-F/LRAmp-R (all } \\
\text { inclusive) (Abou Ghanem- } \\
\text { Sabanadzovic et al. 2012) }\end{array}$ & 50 & MN201920 & $6(0.8)$ & $6^{\mathrm{y}}(98-99)$ & 5 \\
\hline GVA & H587/C995 (Minafra et al. 1997) & 54 & MK317836 & $31(4.3)$ & $6(83-99)$ & 50 \\
\hline GVB & $\begin{array}{l}\text { C410/H28 (Minafra and Hadidi } \\
\text { 1994) }\end{array}$ & 54 & MK789666 & $15(2.1)$ & $5(87-99)$ & 35 \\
\hline GVCV & $\begin{array}{l}\text { GVCV-F1/GVCV-R1 (Zhang } \\
\text { et al. 2011) }\end{array}$ & 52 & & $0(0)$ & $\mathrm{n} / \mathrm{a}$ & \\
\hline ToRSV & ToRSV5/ToRSV6 (Li et al. 2011) & 60 & MN175642 & $8(1.4)$ & $1^{\mathrm{z}} \mathrm{n} / \mathrm{a}$ & 83 \\
\hline GRBV & $\begin{array}{l}\text { GVGF1/GVGR1 (Al Rwahnih } \\
\text { et al. 2013) }\end{array}$ & 60 & MK789665 & $140(24.4)$ & $6(93-99)$ & 99 \\
\hline GPGV & $\begin{array}{l}\text { GPgV5619f/GPgV6668r } \\
\text { (Giampetruzzi et al. 2012) }\end{array}$ & 54 & & $0(0)$ & $\mathrm{n} / \mathrm{a}$ & \\
\hline
\end{tabular}

\footnotetext{
t Representative sequences deposited to the GenBank from this study.

u A total of 721 samples were examined for GLRaV-1, GLRaV-4, GRBV, GVA, and GVB, and a total of 574 samples were examined for ToRSV, GPGV, GVCV, and GRBV.

${ }^{v}$ A number of examined isolates per virus is followed by a range of percentages of nucleotide sequence identity match in parentheses. The majority of Virginia sequences resulted in $95 \%$ or higher identity match, but two GRSPaV, two GVA, and one GVB samples resulted in less than $90 \%$ match. The submitted sequence for each virus represents the majority found in our study.

${ }^{w}$ Percent sequence identity score against the deposited sequence based on the NCBI BLAST accessed on 20 July 2019.

${ }^{x}$ Three primer sets were used for GLRaV-4 to ensure the detection of two strains of GLRaV-4; the accession number for LRAmp-F/LRAmp-R is for an isolate of GLRaV-4.

y GLRaV-4 strains compared for identity match did not include either strain 5 or strain 9 .

${ }^{\mathrm{z}}$ Owing to a poor storage condition, only one of eight ToRSV samples came back as a useful sequence.
} 
samples were tested. All virus samples were identified as the correct target virus species by comparing sequences of each virus's target gene and that of the reference strains in GenBank. Table 1 shows the number of positive vines, nucleotide identity match among Virginia isolates, and number of isolates with more than $95 \%$ identity match to our submitted sequences in GenBank. The low nucleotide identity match with several viruses was owing to a few variants we observed in our sample. The majority of the sequenced samples were $95 \%$ or higher in the sequence identity match; however, two, two, and one isolates of GRSPaV, GVA, and GVB resulted in less than $90 \%$ match. We deposited a representative sequence from the majority for each virus (Table 1).

Vines were often infected by multiple viruses. We found $69 \%$ of samples were positive for at least one virus (Fig. 3). The most prevalent virus among our samples was GRSPaV, which was detected in $54 \%$ of sampled vines. GRBV was the second highest with $24 \%$ positive samples, and ToRSV, GVA, GVB, GLRaV-1, and GLRaV-4 were detected in less than $5 \%$ of the samples (Table 1). GPGV and GVCV were not detected in any samples, indicating the two viruses (GPGV and GVCV) were most likely not present in Virginia vineyards at the time of sampling, but there may be future introductions.

Among the tested seven viruses, a total of 298 (out of 574) vines were infected with one virus (Fig. 3). Single infection of GRSPaV (39\%) was the most common, followed by single infection of GRBV (12\%). A total of 87 vines were positive for two viruses, eight were positive for three viruses, and two were positive for four viruses (Fig. 3). Interestingly, GLRaV-1 and -4 (including strains 5 and 9) were always found with one or more other viruses within the same vine sample, with an exception of one case (Fig. 3).

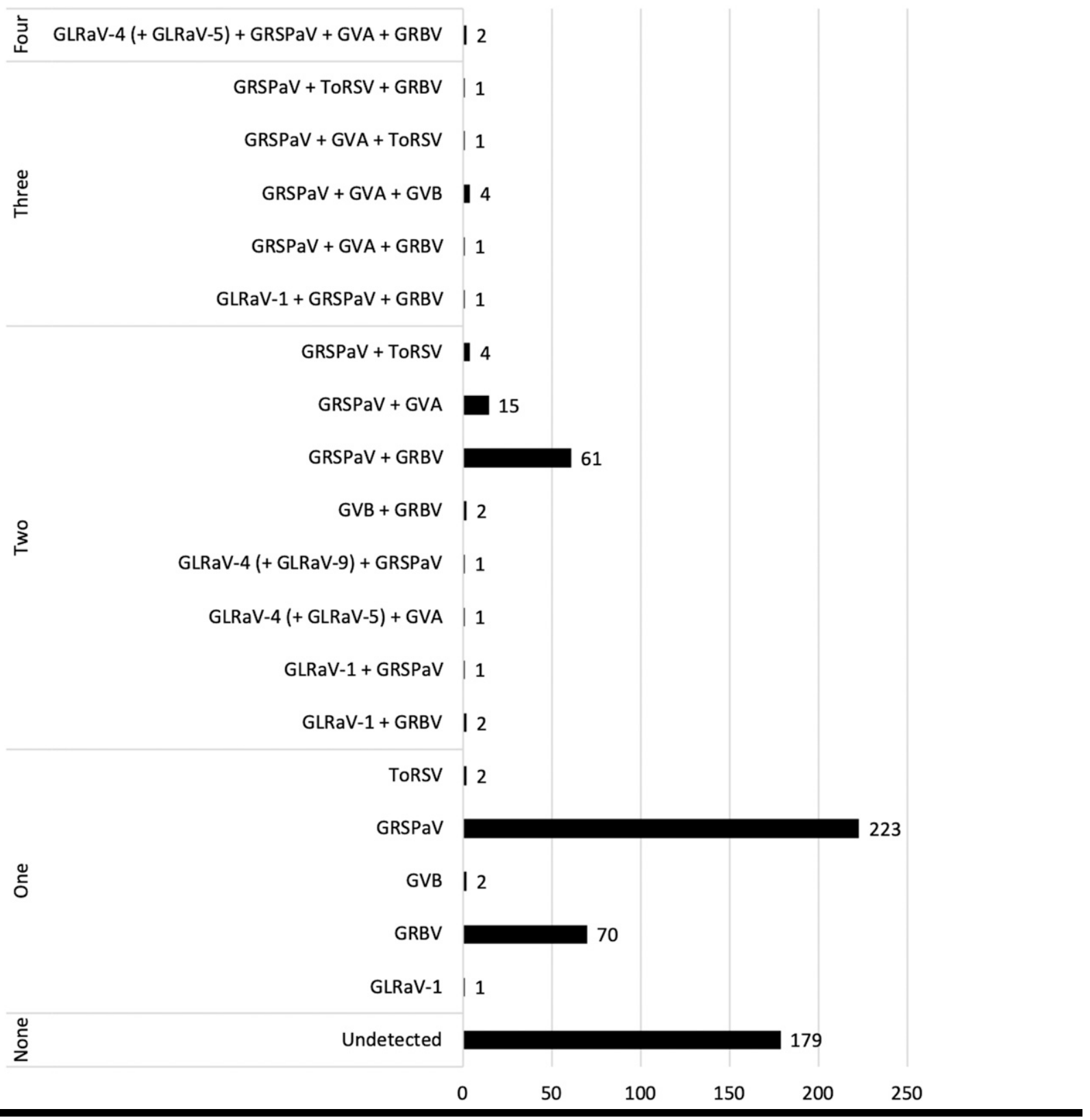

FIGURE 3

Number of vines with single and coinfections of grapevine viruses from the Virginia grapevine virus survey, 2009 to 2014. Vines are categorized based on the number of viruses found and then species of virus. 
The high incidence of GRSPaV was not surprising, because this virus was not regulated in many grapevine certification programs. A study from Syria also detected GRSPaV in more than $72 \%$ of 835 tested vines (Mslmanieh et al. 2006). In contrast, a previous study from Oregon and Washington reported low incidence of GRSPaV (Martin et al. 2005). The effects of GRSPaV infection develop slowly; however, it may become more severe when multiple viruses are found infecting the same vine (Guidoni et al. 1997). Given the high percentage of infestation and many cases of mixed infection (Fig. 3), the importance of GRSPaV to long-term vineyard production needs to be reevaluated.

Nearly 25\% incidence of GRBV (Table 1) is concerning because this disease can directly impact fruit quality parameters (Blanco-Ulate et al. 2017; Wallis and Sudarshana 2016). On the other hand, in a recent survey in Washington, incidence was reported as only $6 \%$ among 2,063 samples (Adiputra et al. 2018), and a study from British Colombia showed only $1.5 \%$ out of 2,000 samples (Poojari et al. 2017).

For measurements of association, Kendall's tau was estimated using PROC CORR of SAS 9.4 (SAS Institute, Cary, NC). Kendall's tau is a nonparametric measure of association in which concordance (= paired observations vary together) and discordance (= paired observations vary differently) of paired observations are calculated, as was done for four commonly identified viruses (Table 2) (Sheskin 2011). A significant $(P \leq 0.05)$ association was found between GVA and GVB and between GVA and GRSPaV (Table 3). These associations between GVA and GVB could be because these viruses are both transmitted by the same mealybug species (Garau et al. 1995; Minafra et al. 1997; Rosciglione and Castellano 1985). On the other hand, two commonly found viruses, GRSPaV and GRBV, were found to be negatively associated, indicating that these two viruses are less likely to be present within the same vine. This disassociation could be owing to different factors. The disassociation could result from differences in the distribution of vectors (although the vector is unknown for GRSPaV), if infected vines tend to show more acute symptoms (i.e., infected vines are removed more readily than others), or if the interaction between these two viruses may favor one over the other. However, more research is required to draw any concrete conclusions.

\section{Effect of Vine Age and the Presence of Mealybugs on the Incidence of Viruses}

Samples were classified into different vine age groups based on approximate planting year. The classification used was pre-1990,

\section{TABLE 2}

Association and disassociation between two viruses based on Kendall's tau (upper right triangle), and the number of coinfections (lower left triangle) among four commonly found grapevine viruses in the Virginia grapevine virus

\begin{tabular}{lcccr}
\multicolumn{5}{c}{ survey, 2009 to $\mathbf{2 0 1 \mathbf { 4 } ^ { \mathbf { z } }}$} \\
Virus & GVA & GVB & GRSPaV & GRBV \\
GVA & & $0.27^{* *}$ & $0.17^{* *}$ & -0.06 \\
& & $<0.001$ & $<0.001$ & 0.17 \\
GVB & 4 & & -0.01 & 0.01 \\
& & & 0.78 & 0.97 \\
GRSPaV & 23 & 6 & & $-0.09 *$ \\
& & & & 0.03 \\
GRBV & 3 & 2 & 66 &
\end{tabular}

${ }^{\mathrm{z}}$ The number on the top is Kendall's tau, and the number on the bottom is the $P$ value. Numbers with one and two asterisks indicate significant association (or disassociation when the number is negative) with $95 \%$ and $99 \%$ confidence level, respectively. 1990s, and post-2000. The wide interval was mainly owing to the lack of specific information from growers. The effect of the age group on the probability of detecting virus-positive vines was examined using a generalized linear mixed model (PROC GLIMMIX, SAS version 9.4), in which the age group was considered as a fixed factor and cultivar and vineyard as random factors. Presence of mealybugs was recorded at the time of sampling, and their effects on the probability of detecting virus-positive vines were examined using the same procedure.

Owing to the lack of sample size for some viruses, only GRSPaV, GVA, GVB, and GRBV data were subjected to the analyses (Table 3). A relationship was observed between vine age and the presence of some viruses. Vine age was a significant factor for GVA and GVB $(P \leq 0.05)$, for which older vines had significantly higher percentages of viruses. However, with both GRSPaV and GRBV, the differences in vine age did not significantly affect the probability of detecting these two viruses $(P>0.05)$ (Table 3$)$. Similar examination of the vine age showed significantly higher occurrences of GLRaV-2 and -3 with older vines in the previous study (Jones et al. 2015).

These results suggest the positive effect of clean plant materials through certification programs such as Foundation Planting Services (FPS), formed in 1958, and the National Clean Plant Network (NCPN), established in 2008 (Alley and Golino 2000; Gergerich et al. 2015). A few grapevine certification programs existed earlier, and these relied heavily on using indicator vines for viruses. However, the FPS and NCPN implemented advanced and more reliable detection techniques for their certification programs, such as ELISA, PCR, and qPCR, after 1988 (Martin et al. 2000).

GLRaV-2, GLRaV-3, GVA, and GVB were listed for the FPS's and NCPN's virus cleanup efforts from early on (Martin et al. 2000). Thus, the lower probabilities of GVA and GVB in recent decades were partially owing to increased availability of cleaner materials. On the other hand, GRSPaV and GRBV, which were not affected by the vine age, were not included until the recently developed Protocol 2010 (Rowhani and Golino 2010). GRSPaV was not included in the previous lists probably owing to the lack of acute effect (Guidoni et al. 1997; Rosa et al. 2011), and GRBV was not discovered until recently (Al Rwahnih et al. 2013). As detection techniques advance and more high-throughput methods are developed, we should see a continuing trend toward cleaner planting materials.

The consistently high incidence of GRBV among vines planted over three decades suggests that infested planting material was probably available for a long time. GRBV has been detected in historic grapevine specimens collected in California in 1940 (Al Rwahnih et al. 2015). New reports from different countries, such as Canada, Korea, Mexico, and Switzerland (Gasperin-Bulbarela et al. 2018; Krenz et al. 2014; Lim et al. 2016) indicate the infected materials have been distributed worldwide. Because one of potential vectors, the threecornered alfalfa hopper (S. festinus), is present in the southeastern United States (Beyer et al. 2017), the involvement of vector insects for GRBV in Virginia is possible. If that was the case, the older vines probably resulted in higher probabilities of infection owing to longer time periods to be exposed to vectors. On the other hand, a recent study in Oregon documented cases of very rapid increase in GRBV-infected vines (Dalton et al. 2019), which could explain the lack of vine-age effect with GRBV in Virginia. Therefore, a further study is warranted.

Effect of cultivar. The sample consisted of a total of 49 different cultivars. The 15 most common cultivars and sample numbers (in parentheses) were Cabernet franc (98 samples), Cabernet Sauvignon 
(97), Merlot (75), Chardonnay (65), Petit Verdot (49), Viognier (31), Vidal blanc (25), Chambourcin (20), Malbec (20), Traminette (19), Chardonel (18), Riesling (17), Petit Manseng (15), Syrah (13), and Norton (12). Many cultivars above are $V$. vinifera, but Vidal blanc, Chambourcin, and Traminette are interspecific hybrids, and Norton is a hybrid of $V$. aestivalis. We examined the effect of cultivar on the probability of detection for each virus using a generalized linear mixed model (PROC GLIMMIX). However, the effect of cultivar was significant $(P \leq 0.05)$ only with ToRSV (Table 4$)$, which was detected only from cultivar Vidal blanc. Some plantings of this hybrid cultivar are own-rooted and more susceptible to infestation by the ToRSV vector, the dagger nematode (X. americanum) (Tuskan and Tolin 1984).

\section{Grape and Gill's Mealybugs Were Commonly Found in Virginia Vineyards}

Mealybug species identification. Individual female mealybug samples were ground in liquid nitrogen. The powdered tissue was transferred to a 1.5-ml microcentrifuge tube and then subjected to total genomic DNA extraction through the QIAGEN DNeasy Blood and Tissue Kit (Qiagen) following the manufacturer's protocol. The extracted genomic DNA was stored at $-80^{\circ} \mathrm{C}$ until used in the vineyard mealybug multiplex PCR (Daane et al. 2011; Jones et al. 2015). The multiplex-PCR products were purified following the manufacturer's standard protocol for the QIAquick PCR purification kit (Qiagen), and randomly selected samples for each species were sequenced as described above.

In addition to the vineyard mealybug multiplex PCR, PCR products from a simplex PCR for the amplification of the cytochrome oxidase subunit 1 gene were sequenced to confirm mealybug species identification. Primers used for amplification were C1-J-2183 (5'-CAACATTTATTTTGATTTTTTGG-3') and C1-N-2568 (5'-GCWACWACRTAATAKGTATCATG-3') (Brady et al. 2000; Simon et al. 1994). The parameters for the cytochrome oxidase subunit $1 \mathrm{PCR}$ were $95^{\circ} \mathrm{C}$ for $7 \mathrm{~min}$, followed by 40 cycles of $95 \mathrm{C}$ for $1 \mathrm{~min}, 45^{\circ} \mathrm{C}$ for $1 \mathrm{~min}$, and $72^{\circ} \mathrm{C}$ for $1.5 \mathrm{~min}$, with final extension at $72^{\circ} \mathrm{C}$ for $5 \mathrm{~min}$. These PCR products were purified and sequenced in the same manner as the products from the vineyard mealybug multiplex PCR.

A total of 100 mealybug samples were collected from 39 vineyard blocks (block = cultivar in this study) from nine different vineyards. Mealybugs sampled in vineyards were found along trunks, cordons, shoots, petioles, within clusters, and the undersides of leaves. We found 67 grape mealybugs ( $P$. maritimus), 31 Gill's mealybugs $(F$. gilli), and two obscure mealybugs (Pseudococcus viburni, GenBank accession number MK578586). Based on our knowledge, this is the first report of $P$. viburni in Virginia. $P$. viburni is a common grape pest in California and known for its capability to transmit GLRaV-3 (Daane et al. 2012; Golino et al. 2002). With one case of the striped mealybug (Ferrisia virgata) reported earlier (Jones et al. 2015), now we have a total of four mealybug species confirmed in Virginia vineyards. In five vineyards, grape and Gill's mealybugs were found together on the same vine. Both striped and obscure mealybugs were found in the same vineyard.

Mealybug species we found (grape, obscure, and Gill's mealybugs) can transmit one or more viruses among GLRaV-1, GLRaV3, GLRaV-4, GVA, and GVB and have a wide host range that includes grapevines, figs, apples, and citrus crops (Golino et al. 2002; Tsai et al. 2010). Both striped and Gill's mealybugs are thought to be native to the southeastern United States and have been found in vineyards as well as in pistachio and almond orchards in California (Haviland et al. 2006; Wistrom et al. 2016).

This and our previous study (Jones et al. 2015) covered a total of 116 vineyards to collect a total of 212 mealybugs from 15 vineyards; however, the vine mealybug (Planococcus ficus) was not found in Virginia. The vine mealybug is the major concern in California owing to its wide host range, ability to produce multiple overlapping generations per year, effectiveness of transmission of GLRaVs, and capability to cause direct damages on the grapevine (Mahfoudhi et al. 2009; Tsai et al. 2010). Nonetheless, with the high

\begin{tabular}{|c|c|c|}
\hline \multicolumn{3}{|c|}{$\begin{array}{c}\text { TABLE } 4 \\
\text { Effect of cultivar on grapevine virus incidence, Virginia } \\
\text { grapevine survey, } 2009 \text { to } 2014^{z}\end{array}$} \\
\hline Virus & F statistic & $P$ value \\
\hline GLRaV-1 & 0.92 & 0.63 \\
\hline GRSPaV & 0.29 & 1.00 \\
\hline GVA & 1.07 & 0.36 \\
\hline GVB & 0.63 & 0.97 \\
\hline ToRSV & 6.73 & $<0.001$ \\
\hline GRBV & 1.02 & 0.45 \\
\hline
\end{tabular}

${ }^{\mathrm{z}} F$ statistics and $P$ values from a generalized linear mixed model (GLIMMIX, SAS 9.4) are shown.

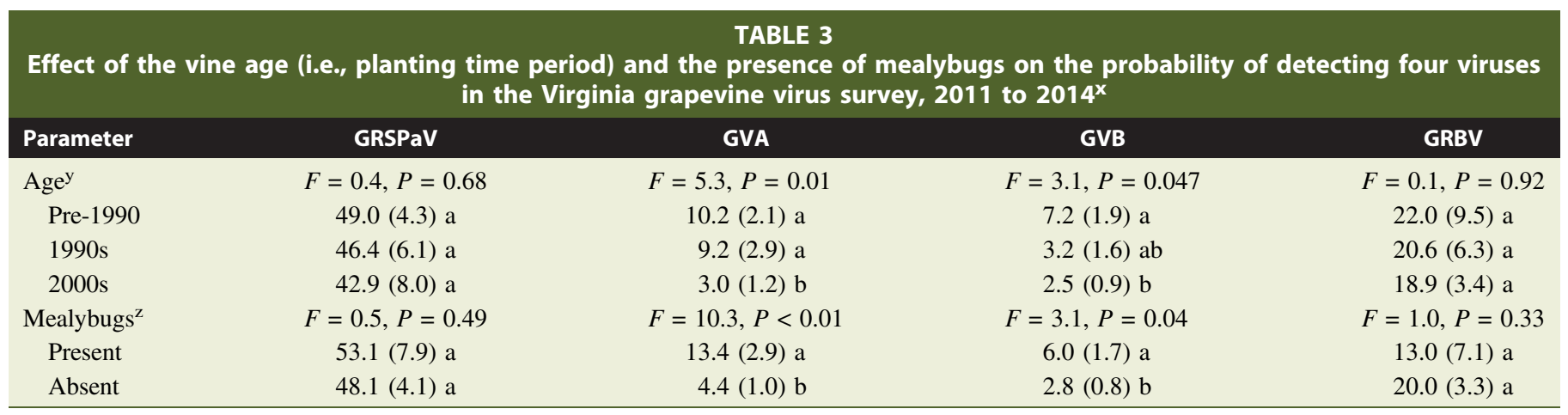

${ }^{\mathrm{x}} F$ statistics and $P$ values from a generalized linear mixed model (GLIMMIX, SAS 9.4) are shown. For each classification, an estimated percentage (i.e., probability $\times 100$ ) of virus-infected vines and standard error in parentheses are shown. The same letter after the number indicates that the numbers were not significantly different $(P \leq 0.05)$ based on the Fisher's LSD (for age) or $t$ test (for mealybugs).

${ }^{y}$ Age of vine samples were grouped according to the planting time period. A total of 21, 65, and 486 samples were from the pre-1990, 1990s, and 2000s time periods, respectively.

${ }^{\mathrm{z}}$ Vineyards were grouped based on presence or absence of mealybugs in the vineyard. 
incidence of both viruses and mealybugs in the state, it is important for growers to use appropriate control measures.

Presence of mealybugs was associated with mealybug-vectored viruses. When the effect of the presence of mealybugs in a vineyard was tested against the probability of vines in the same vineyard being infected with viruses, the result was significant $(P \leq 0.05)$ with mealybug-vectored GVA and GVB (Table 3 ) but not with GRSPaV and GRBV, which were not vectored by mealybugs, as expected. The trend was similar in our previous study in which we found a significant positive association between the presence of mealybugs and GLRaV-3 but not with GLRaV-2, which is not vectored by mealybugs (Jones et al. 2015).

\section{Summary}

Based on our knowledge, this is the first report of GLRaV-1, GLRaV-4 (including strains 5 and 9), GRSPaV, GVA, GVB, and $P$. viburni from the state of Virginia (U.S.A.). Along with GLRaV-2, GLRaV-3, GFkV, ToRSV, GRBV, $P$. maritimus, $F$. gilli, and $F$. virgata reported earlier (Jones et al. 2015), a total of 10 virus species and four mealybug species have been found in Virginia vineyards. GRSPaV and GRBV were found in high numbers, and coinfections of multiple grapevine viruses within the same grapevine were common. When the data are pooled and examined at vineyard level, $91 \%$ (106 out of 116) of vineyards had at least one vine that was positive for one (or more) tested viruses. It is clear that grapevine virus infections, alongside their vectors, are widespread in Virginia and, thus, management strategies are needed to control potential spreads. Results from this and our previous study (Jones et al. 2015) emphasize the importance of clean plant material, and our other study (Jones and Nita 2016) identified two insecticides that are effective in reducing mealybug populations. Therefore, clean plant material programs, insect vector management, and consistent grapevine virus testing are highly suggested for grape growers in the state of Virginia to keep their vines highly productive.

\section{Acknowledgments}

We thank the vineyard owners who agreed to participate and help with our studies.

\section{Literature Cited}

Abou Ghanem-Sabanadzovic, N., Sabanadzovic, S., Gugerli, P., and Rowhani, A. 2012. Genome organization, serology and phylogeny of grapevine leafrollassociated viruses 4 and 6: Taxonomic implications. Virus Res. 163:120-128.

Adiputra, J., Kesoju, S. R., and Naidu, R. A. 2018. The relative occurrence of grapevine leafroll-associated virus 3 and grapevine red blotch virus in Washington State vineyards. Plant Dis. 102:2129-2135.

Alkowni, R., Rowhani, A., Daubert, S., and Golino, D. 2004. Partial characterization of a new ampelovirus associated with grapevine leafroll disease. J. Plant Pathol. 86:123-133.

Al Rwahnih, M., Dave, A., Anderson, M. M., Rowhani, A., Uyemoto, J. K., and Sudarshana, M. R. 2013. Association of a DNA virus with grapevines affected by red blotch disease in California. Phytopathology 103:1069-1076.

Al Rwahnih, M., Rowhani, A., and Golino, D. 2015. First report of grapevine red blotch-associated virus in archival grapevine material from Sonoma County, California. Plant Dis. 99:895.

Alley, L., and Golino, D. A. 2000. The origins of the grape program at Foundation Plant Materials Service. Pages 222-230 in: Proceedings of the ASEV 50th Anniversary Meeting, Seattle, Washington. http://iv.ucdavis.edu/ files/24398.pdf

Bahder, B. W., Poojari, S., Alabi, O. J., Naidu, R. A., and Walsh, D. B. 2013. Pseudococcus maritimus (Hemiptera: Pseudococcidae) and Parthenolecanium corni (Hemiptera: Coccidae) are capable of transmitting grapevine leafroll-associated virus 3 between Vitis $\times$ labruscana and Vitis vinifera. Environ. Entomol. 42:1292-1298.

Bahder, B. W., Zalom, F. G., Jayanth, M., and Sudarshana, M. R. 2016. Phylogeny of Geminivirus coat protein sequences and digital PCR aid in identifying Spissistilus festinus as a vector of grapevine red blotch-associated virus. Phytopathology 106:1223-1230.

Beyer, B. A., Srinivasan, R., Roberts, P. M., and Abney, M. R. 2017. Biology and management of the threecornered alfalfa hopper (Hemiptera: Membracidae) in alfalfa, soybean, and peanut. J. Integr. Pest Manag. 8:10.

Blanco-Ulate, B., Hopfer, H., Figueroa-Balderas, R., Ye, Z., Rivero, R. M., Albacete, A., Pérez-Alfocea, F., Koyama, R., Anderson, M. M., Smith, R. J., Ebeler, S. E., and Cantu, D. 2017. Red blotch disease alters grape berry development and metabolism by interfering with the transcriptional and hormonal regulation of ripening. J. Exp. Bot. 68:1225-1238.

Boscia, D., Savino, V., Minafra, A., Namba, S., Elicio, V., Castellano, M. A., Gonsalves, D., and Martelli, G. P. 1993. Properties of a filamentous virus isolated from grapevines affected by corky bark. Arch. Virol. 130:109-120.

Brady, S. G., Gadau, J., and Ward, P. S. 2000. Systematics of the ant genus Camponotus (Hymenoptera: Formicidae): A preliminary analysis using data from the mitochondrial gene cytochrome oxidase I. Pages 131-139 in: Hymenoptera: Evolution, Biodiversity and Biological Control. Fourth International Hymenoptera Conference, Held in Canberra, Australia, in January 1999. CSIRO Publishing, Clayton, VIC, Australia.

Charles, J. G., Cohen, D., Walker, J. T. S., Forgie, S. A., Bell, V. A., and Breen, K. C. 2006. A review of the ecology of grapevine leafroll associated virus type 3(GLRaV-3).N. Z. Plant Prot. 59:330-337.

Cooper, M. L., Daugherty, M. P., Jeske, D. R., Almeida, R. P. P., and Daane, K. M. 2018. Incidence of grapevine leafroll disease: Effects of grape mealybug (Pseudococcus maritimus) abundance and pathogen supply. J. Econ. Entomol. 111:1542-1550.

Daane, K. M., Almeida, R. P. P., Bell, V. A., Walker, J. T. S., Botton, M., Fallahzadeh, M., Mani, M., Miano, J. L., Sforza, R., Walton, V. M., and Zaviezo, T. 2012. Biology and management of mealybugs in vineyards. Pages 271-307 in: Arthropod Management in Vineyards: Pests, Approaches, and Future Directions. N. J. Bostanian, C. Vincent, and R. Isaacs, eds. Springer, Dordrecht, the Netherlands.

Daane, K. M., Middleton, M. C., Cooper, M. L., Walton, V. M., Walsh, D. B., Zaviezo, T., and Almeida, R. P. 2011. Development of a multiplex PCR for identification of vineyard mealybugs. Environ. Entomol. 40:1595-1603.

Dalton, D. T., Hilton, R. J., Kaiser, C., Daane, K. M., Sudarshana, M. R., Vo, J., Zalom, F. G., Buser, J. Z., and Walton, V. M. 2019. Spatial associations of vines infected with grapevine red blotch virus in Oregon vineyards. Plant Dis. 103:1507-1514.

Garau, R., Prota, V. A., Boscia, D., Fiori, M., and Prota, U. 1995. Pseudococcus affinis Mask., new vector of grapevine trichoviruses A and B. Vitis 34:67-68.

Gasperin-Bulbarela, J., Licea-Navarro, A. F., Pino-Villar, C., HernandezMartinez, R., and Carrillo-Tripp, J. 2018. First report of grapevine red blotch virus in Mexico. Plant Dis. 103:381.

Gergerich, R. C., Welliver, R. A., Osterbauer, N. K., Kamenidou, S., Martin, R. R., Golino, D. A., Eastwell, K., Fuchs, M., Vidalakis, G., and Tzanetakis, I. E. 2015. Safeguarding fruit crops in the age of agricultural globalization. Plant Dis. 99:176-187.

Giampetruzzi, A., Roumi, V., Roberto, R., Malossini, U., Yoshikawa, N., La Notte, P., Terlizzi, F., Credi, R., and Saldarelli, P. 2012. A new grapevine virus discovered by deep sequencing of virus- and viroid-derived small RNAs in cv Pinot gris. Virus Res. 163:262-268.

Golino, D. A., Sim, S. T., Gill, R., and Rowhani, A. 2002. California mealybugs can spread grapevine leafroll disease. Calif. Agric. 56:196-201.

Guidoni, S., Mannini, F., Ferrandino, A., Argamante, N., and Di Stefano, R. 1997. The effect of grapevine leafroll and rugose wood sanitation on agronomic performance and berry and leaf phenolic content of a Nebbiolo clone (Vitis vinifera L.). Am. J. Enol. Vitic. 48:438-442.

Guo, Q., Honesty, S., Xu, M. L., Zhang, Y., Schoelz, J., and Qiu, W. 2014. Genetic diversity and tissue and host specificity of Grapevine vein clearing virus. Phytopathology 104:539-547.

Haviland, D., Beede, R., Godfrey, K., and Daane, K. 2006. Ferrisia gilli: A new mealybug pest of pistachios and other deciduous crops. Publication 8207. Division of Agriculture and Natural Resources, University of California, Oakland, CA.

Jelkmann, W., Mikona, C., Turturo, C., Navarro, B., Rott, M. E., Menzel, W., Saldarelli, P., Minafra, A., and Martelli, G. P. 2012. Molecular characterization and taxonomy of grapevine leafroll-associated virus 7. Arch. Virol. 157:359-362.

Jones, T. J., and Nita, M. 2016. Spatio-temporal association of GLRaV-3infected grapevines, and effect of insecticidal treatments on mealybug populations in Virginia vineyards. Eur. J. Plant Pathol. 145:885-900.

Jones, T. J., Rayapati, N. A., and Nita, M. 2015. Occurrence of grapevine leafroll associated virus-2, -3 and grapevine fleck virus in Virginia, U.S.A., and factors affecting virus infected vines. Eur. J. Plant Pathol. 142:209-222. 
Kovacs, L. G., Hanami, H., Fortenberry, M., and Kaps, M. L. 2001. Latent infection by leafroll agent GLRaV-3 is linked to lower fruit quality in FrenchAmerican hybrid grapevines Vidal blanc and St. Vincent. Am. J. Enol. Vitic. 52:254-259.

Krenz, B., Thompson, J. R., Fuchs, M., and Perry, K. L. 2012. Complete genome sequence of a new circular DNA virus from grapevine. J. Virol. 86:7715.

Krenz, B., Thompson, J. R., McLane, H., Fuchs, M., and Perry, K. L. 2014. Grapevine red blotch-associated virus is widespread in the United States. Phytopathology 104:1232-1240.

Li, R., Mock, R., Fuchs, M., Halbrendt, J., Howell, B., and Liu, Z. 2011. Characterization of the partial RNA1 and RNA2 3' untranslated region of tomato ringspot virus isolates from North America. Can. J. Plant Pathol. 33:94-99.

Lim, S., Igori, D., Zhao, F., Moon, J. S., Cho, I.-S., and Choi, G.-S. 2016. First report of grapevine red blotch-associated virus on grapevine in Korea. Plant Dis. 100:1957.

Lunden, S., Meng, B., Avery, J., and Qiu, W. 2010. Association of grapevine fanleaf virus, tomato ringspot virus and grapevine rupestris stem pittingassociated virus with a grapevine vein-clearing complex on var. Chardonnay. Eur. J. Plant Pathol. 126:135-144

Mahfoudhi, N., Digiaro, M., and Dhouibi, M. H. 2009. Transmission of grapevine leafroll viruses by Planococcus ficus (Hemiptera: Pseudococcidae) and Ceroplastes rusci (Hemiptera: Coccidae). Plant Dis. 93:999-1002.

Martelli, G. P. 2014. Directory of virus and virus-like diseases of the grapevine and their agents. J. Plant Pathol. 96:1-136.

Martelli, G. P., Ghanem-Sabanadzovic, N. A., Agranovsky, A. A., Al Rwahnih, M., Dolja, V. V., and Dovas, C. I. 2012. Taxonomic revision of the family Closteroviridae with special reference to the Grapevine leafroll-associated members of the genus Ampelovirus and the putative species unassigned to the family. J. Plant Pathol. 94:7-19.

Martin, R. R., Eastwell, K. C., Wagner, A., Lamprecht, S., and Tzanetakis, I. E. 2005. Survey for viruses of grapevine in Oregon and Washington. Plant Dis. 89:763-766.

Martin, R. R., James, D., and Lévesque, C. A. 2000. Impact of molecular diagnostic technologies on plant disease management. Annu. Rev. Phytopathol. 38:207-239.

Meng, B., Johnson, R., Peressini, S., Forsline, P. L., and Gonsalves, D. 1999. Rupestris stem pitting associated virus-1 is consistently detected in grapevines that are infected with rupestris stem pitting. Eur. J. Plant Pathol. 105:191-199.

Minafra, A., and Hadidi, A. 1994. Sensitive detection of grapevine virus A, B, or leafroll-associated III from viruliferous mealybugs and infected tissue by cDNA amplification. J. Virol. Methods. https://doi.org/10.1016/01660934(94)90076-0

Minafra, A., Saldarelli, P., and Martelli, G. P. 1997. Grapevine virus A: Nucleotide sequence, genome organization, and relationship in the Trichovirus genus. Arch. Virol. 142:417-423.

Morelli, M., Catarino, A. de M., Susca, L., Saldarelli, P., Gualandri, V., and Martelli, G. P. 2014. First report of grapevine Pinot gris virus from table grapes in southern Italy. J. Plant Pathol. 96:431-439.

Mslmanieh, T., Digiaro, M., Elbeaino, T., Boscia, D., and Martelli, G. P. 2006. Viruses of grapevine in Syria. EPPO Bull. 36:523-528.

Naidu, R., Rowhani, A., Fuchs, M., Golino, D., and Martelli, G. P. 2014. Grapevine leafroll: A complex viral disease affecting a high-value fruit crop. Plant Dis. 98:1172-1185.

Naidu, R. A., and Mekuria, T. A. 2010. First report of grapevine fleck virus from Washington vineyards. Plant Dis. 94:784.

Osman, F., Leutenegger, C., Golino, D., and Rowhani, A. 2007. Real-time RTPCR (TaqMan $囚)$ assays for the detection of grapevine leafroll associated viruses 1-5 and 9. J. Virol. Methods 141:22-29.
Poojari, S., Lowery, D. T., Rott, M., Schmidt, A. M., and Úrbez-Torres, J. R. 2017. Incidence, distribution and genetic diversity of grapevine red blotch virus in British Columbia. Can. J. Plant Pathol. 39:201-211.

Qiu, W. 2007. Characterization of a severe virus-like disease in Chardonnay grapevines in Missouri. Plant Health Prog. 8. doi: 10.1094/PHP-2007-111901-BR.

Rosa, C., Jimenez, J. F., Margaria, P., and Rowhani, A. 2011. Symptomatology and effects of viruses associated with rugose wood complex on the growth of four different rootstocks. Am. J. Enol. Vitic. 62:207-213.

Rosciglione, B., and Castellano, M. A. 1985. Further evidence that mealybugs can transmit grapevine virus A (GVA) to herbaceous hosts. Phytopathol. Mediterr. 24:186-188.

Rosenberger, D. A., Harrison, M. B., and Gonsalves, D. 1983. Incidence of apple union necrosis and decline, tomato ringspot virus, and Xiphinema vector species in Hudson Valley orchards. Plant Dis. 67:356-360.

Rowhani, A., Biardi, L., Johnson, R., Saldarelli, P., Zhang, Y. P., Chin, J., and Green, M. 2000. Simplified sample preparation method and one-tube RTPCR for grapevine viruses. Page 148 in: Proceedings of the 13th International Council for the Study of Viruses and Virus-Like Diseases of the Grapevine, 12-17 March 2000, Adelaide, South Australia.

Rowhani, A., and Golino, D. 2010. Grapevine disease testing protocol 2010. FPS Grape Progr. Newsl. (Oct. 2010):10-11.

Saldarelli, P., Giampetruzzi, A., Morelli, M., Malossini, U., Pirolo, C., Bianchedi, P., and Gualandri, V. 2015. Genetic variability of grapevine Pinot gris virus and its association with grapevine leaf mottling and deformation. Phytopathology 105:555-563.

Sheskin, D. J. 2011. Handbook of Parametric and Nonparametric Statistical Procedures, 5th Ed. CRC Press, Boca Raton, FL.

Simon, C., Frati, F., Beckenbach, A., Crespi, B., Liu, H., and Flook, P. 1994. Evolution, weighting, and phylogenetic utility of mitochondrial gene sequences and a compilation of conserved polymerase chain reaction primers. Ann. Entomol. Soc. Am. 87:651-701.

Teliz, D., Lownsberry, B. F., and Grogan, R. G. 1966. Transmission of tomato ringspot virus by Xiphinema americanum (Abstr.). Phytopathology 56:151.

Tsai, C.-W., Rowhani, A., Golino, D. A., Daane, K. M., and Almeida, R. P. P. 2010. Mealybug transmission of grapevine leafroll viruses: An analysis of virus-vector specificity. Phytopathology 100:830-834.

Tuskan, P. G., and Tolin, S. A. 1984. Properties of grape and soybean isolates of tomato ringspot virus (Abstr.). Phytopathology 75:808.

Uyemoto, J. K., Cummins, J. R., and Abawi, G. S. 1977. Virus and virus-like diseases affecting grapevines in New York vineyards. Am. J. Enol. Vitic. 28: 131-136.

Virginia Wine Board. 2017. The Economic Impact of Wine and Wine Grapes on the State of Virginia, 2015. A Frank, Rimerman + Co. LLP, St. Helena, CA.

Wallis, C. M., and Sudarshana, M. R. 2016. Effects of grapevine red blotchassociated virus (GRBV) infection on foliar metabolism of grapevines. Can. J. Plant Pathol. 38:358-366.

Wistrom, C. M., Blaisdell, G. K., Wunderlich, L. R., Almeida, R. P. P., and Daane, K. M. 2016. Ferrisia gilli (Hemiptera: Pseudococcidae) transmits grapevine leafroll-associated viruses. J. Econ. Entomol. 109:15191523.

Wolpert, J. A., and Vilas, E. P. 1992. Effect of mild leafroll disease on growth, yield, and fruit maturity indices of Riesling and Zinfandel. Am. J. Enol. Vitic. 43:367-369.

Zhang, Y., Singh, K., Kaur, R., Qiu, W., and Darr, W. H. 2011. Association of a novel DNA virus with the grapevine vein-clearing and vine decline syndrome. Phytopathology 101:1081-1090. 